\title{
MICHAEL GOLD ON WALT WHITMAN
}

\author{
RICHARD TUERK
}

As SEVERAL SCHOLARS have noted, for Michael Gold, Walt Whitman was the most important author of the American Renaissance. ${ }^{1}$ One even writes that Gold "adored" Whitman and "emulated" his style, ${ }^{2}$ and another finds Gold's style, "at least when he was being idealistic," "plausibly Whitmaniacal."3 In 1953, looking back on his career as an author, Gold himself declared: "Walt Whitman was the greatest influence of my youth" and added: "He is part of me, for better or worse."4 Most of Gold's verse was written with a Whitmanesque line. And in his prose, he saw himself and his fellow radical writers as Whitman's descendants. Yet no one has examined in detail Gold's attitudes toward and uses of Whitman.

As author of the best-selling ferws Without Money (1930), editor of the New Masses, alone from 1928 to 1931 and as part of a group through most of the thirties until 1939, and author of a daily column in the Daily Worker, Gold had a tremendous impact on American radical literature and literary thought. As one critic writes, by 1930, Gold was "a recognized spokesman for and a power only within the literary left." 5 By 1930, however, the literary left was rapidly growing into a major force in American literature, as a partial list of contributors to the New Masses during the first year Gold edited it indicates: it published such writers as Dorothy Day, John Dos Passos, Alfred Kreymborg, Louis Untermeyer, Kenneth Fearing, Stanley Burnshaw, Horace Gregory, Scott Nearing, Floyd Dell, Upton Sinclair, Theodore Dreiser, Art Young, Josephine Herbst, Malcolm Cowley, William Carlos Williams, V. F. Calverton, even Ezra Pound! And Gold's review of several of Thornton Wilder's plays in the 20 October 1930 issue of the New Republic caused waves felt far beyond the literary left. ${ }^{6}$ Thus, in terms of literary history, his ideas on Whitman were and are of some importance.

Gold typically saw Whitman as a major-perhaps the major-part of an American political and literary tradition beginning with the Revolution and leading to a second American revolution that Gold felt was inevitably to be led by the Communist Party in America, to which he belonged for most of his life. He felt that he and his fellow radical writers were working in an unbroken tradition that went back politically to Thomas Jefferson. In literature, he traced the line to what in 1928 he called "the revolutionary writings of Whitman, Thoreau, Emerson."7 In 1935, he included Whitman, along with Thoreau, Emerson, and Mark Twain, as one of "the spiritual forefathers of the proletarian writers of America, and the champions of the American people," and he told the readers of the Daily Worker, "It is time we understood this better, and made them our own."8 In 1941, he wrote in The Hollow Men of "a major tradition in American democratic literature, the great 
tradition of Emerson, Whittier, Thoreau, and Walt Whitman." This tradition, "closer to the people" than that of T. S. Eliot and Ezra Pound, was "courageously optimistic"; it was a tradition of "socialism and revolt."9 Gold felt that, as a Communist and sometime laborer, he belonged to this tradition.

For Gold, Whitman represented the masses, whom Gold felt to be the true Americans. In 1933, for example, in "Out of the Fascist Unconscious," he wrote that America "is great because it was founded on a democratic revolution" that "continues in the hearts of hundreds of thousands of Kentucky miners, Chicago stockyard butchers and Tampa cigarmakers, Oregon lumberjacks and New England weavers." These workers, along with "sharecroppers, sailors and gandy dancers," are, for Gold, the real owners of America, for, as he wrote, what Walt Whitman said once "needs to be said again and again; every land belongs to those who fertilize it with their blood and sweat." 10 Thus, seeing Whitman (and incidentally himself) as a worker, he placed Whitman among the people he felt to be the true heirs of the American revolution, all of whom the Communist Party claimed to represent.

In his early essay, "Towards Proletarian Art," written in 1921, when he was still using the name Irwin Granich, Gold admitted that Whitman made "one mistake, and it was the mistake of his generation. He dreamed the grand dream of political democracy, and thought it could express in completion all the aspirations of proletarian man."11 That Whitman believed in political democracy is an assertion with which his biographer, Gay Wilson Allen, would agree. Whitman, Allen writes, "saw democracy not as a dated fact but as a dynamic process of becoming, whereby the society could progressively improve and purify itself; in which individuals were constantly tested, exercised, and stimulated to grow stronger and better in the struggle."12 Gold, however, felt that political democracy was not enough; he felt true democracy was not possible under capitalism; ${ }^{13}$ only under the dictatorship of the proletariat could true democracy-that is, economic democracy-be achieved. ${ }^{14}$

Still, according to Gold, "Walt, in his poetry, had intuitively arrived at the proletarian art, though his theory had fallen short of the entire truth." 15 Consequently, in 1935, Gold called Whitman "America's first proletariat poet." 16 And in 1944, he declared that Whitman "is now recognized as the supreme poetic voice of American democracy."17

"Towards Proletarian Art" is one of Gold's earliest essays treating literary history. In fact, Michael Folsom, the foremost authority on Gold, calls it "the first significant call in this country for the creation of a distinctly and militantly working-class culture." 18 In it, Gold discussed extensively Whitman's seminal role in the formation of American proletarian art, precisely the kind of art in which Gold was interested and to which most critics say fews Without Money belongs. Gold and his contemporaries are, Gold 
wrote, "Walt Whitman's Spawn," as he entitled the section of the essay that deals directly with Whitman, whom he called "The heroic spiritual grandfather of our generation in America." Whitman was a "giant" who "knew all that we are still stumbling after." Thus, he became for Gold a mythic figure. Dwelling "among the masses," from them "he drew his strength. From the obscure lives of the masses he absorbed those deep affirmations of the instinct that are his glory." $19 \mathrm{He}$ was concerned with

those great, simple farmers and mechanics and ditch-diggers who are to be found everywhere among the masses - those powerful, natural persons whose heroism needs no drug of fame or applause to enable them to continue; those humble, mighty parts of the mass, whose selfsufficiency comes from their sense of solidarity, not from any sense of solitariness. ${ }^{20}$

Walt's successors failed, Gold felt, because they could not write as members of the masses:

Walt still lived in the rough equalitarian times of a semi-pioneer America, but his successors were caught in the full rising of the industrial expansion. They could not possibly escape its subtle class psychologies. ${ }^{21}$

But by 1921, Gold felt that the "brain and heart" of the masses, "embodied in the revolutionary element among them, are aroused, and they can ... follow him [Whitman] in the massive labors of the earth-built proletarian culture."22 American "attempts to carry on the work of old Walt ... have failed" and will continue to fail, Gold wrote, "while the propagandists still lack Walt's knowledge that a mighty national art cannot arise save out of the soil of the masses." They have made their appeal "to the leisured class, who happen to be at present our intellectuals." But the "roots" of American culture "must be in the fields, factories and workshops . . . in the American life."23 It is true that in the 1855 edition of Leaves of Grass Whitman called himself "one of the roughs." ${ }^{24} \mathrm{He}$ worked at times as a printer and carpenter; thus, according to Gold, Whitman was himself a worker who recognized that from the workers and farmers-Gold's real Americans-culture must grow.

In 1928, Gold commented on the importance of the Wilsonian writers, especially, it seems, the radicals associated with the Masses, the socialist magazine that published Gold's first works:

It was Walt, and the mounting tide of Socialism in pre-war America that produced such startling phenomena as a nakedly feminist poet like Edna Millay, or, who chose to sing of ditchdigging hunkies and department store girls like Carl Sandburg.

Walt was politically conscious, as were all the Civil War writers, and he tried to put that consciousness into poetry. It affected the way he looked at women, or a tree, or a ferryboat. And the Wilsonian writers did the same. ${ }^{25}$

Although in 1941 Gold was to call the twenties "a morbid and rather petty literary decade," 26 in 1929 , he felt that the radical writers working from about 
1914 to 1926 were involved in "a Renaissance, the last desperate geyser-pour of the democratic passion that had enlarged the hearts and pens of Walt Whitman and his contemporaries." Large numbers saw Whitman "as their fountainhead." They "established him as America's chief poet." Teaching "them to see America for the first time," he "inspired them to rise from their book dreams of Keats' nightingale and Tennyson's swans, to walk in their own American sun." They learned from him "to push and crowd with the American mobman at baseball games and picnics, to love their own dooryard lilacs, and the robins of America, and the traffic roar and wheatfield blaze of America." 27

Other radical writers of the twenties and thirties - most notably Granville Hicks, another member of the Communist Party-recognized that Whitman repeatedly echoed Emerson's idea of self-reliant individualism; Hicks wrote that one of Whitman's flaws was a belief in "the unlimited expression of the individual will." 28 Although in "One's-Self I Sing" Whitman uttered "the word Democratic, the word En-Masse," he also wrote: "One's-Self I sing, a simple separate person." 29 In 1935, Gold recognized that "Walt Whitman reflected his period" and was accordingly "marked by the individualism of early America" and that in him "the spirit of the first American revolution often took the form of a mystical egotism." 30

But usually, Gold ignored Whitman's emphasis on the separate self in favor of his emphasis on what Gold called "mobman," an emphasis more consonant with that of the Party with its concern for classes rather than individuals and for dialectical materialism rather than individual initiative. After all, Gold himself was attacked by a Communist reviewer of fews Without Money for writing "without reference to the mass" and for not fully resolving "the struggle between the ideal of the triumphant individual and the mass" in his book. ${ }^{31}$ Perhaps Gold did not want similar criticisms leveled at his idol. Moreover, the Communist Party, whose theorists prided themselves on being "scientific," would not appreciate Whitman's "mystical egotism," another aspect of his writing that Gold usually ignored. In fact, in "Towards Proletarian Art," he even wrote that to call Whitman "a prophet of individualism" is "the usual blunder of literature. Walt knew the masses too well to believe that any individual could rise in intrinsic value above them." 32 And in 1929, Gold wrote that "American intellectuals think they are individualists. . . . Some of them say it is indispensable to 'Art.' It is not." It "leads only to little cafe cliques and minor eccentrics. Dante, Goethe, Whitman, Shakespeare; few of the giants have been individualists. They shared the world-vision of their times." 33 Serving as a model for the radical writers of the twenties and thirties who responded to Gold's call for proletarian literature, Gold's version of Whitman was thus willing to sacrifice himself for what he felt was the greater cause of the masses. Consequently, he achieved the plane of the giants in world literature.

As far as Gold was concerned, this sacrifice in itself, as indicated above, 
was a major factor contributing to Whitman's greatness: "We know and assert that culture is a social product," Gold declared in 1930. "It could not be otherwise. Who could expect a Walt Whitman at the court of Louis the Fourteenth?" 34 Thus, Gold the Marxist used Whitman to refute the Romantic notion that the individual rather than the relentless activity of history as manifested through the classes creates culture. According to Gold's worldview, like nations and classes, the individual is caught in the inexorable stream of history. Resistance is futile; working with the flow leads to greatness.

In 1932, Gold credited Whitman with a major role in having led him on his present path: "I took Shelley, Blake, and Walt Whitman quite literally. They were my real guides to revolutionary action." 35 Whether Whitman could serve as a valid guide to revolutionary action is another matter. Richard Chase, in Walt Whitman Reconsidered, writes of Whitman's "life-long belief in free trade" and calls Democratic Vistas in particular "conservative, individualistic, and unhistorical."36 In his pamphlet Walt Whitman, in fact, Chase asserts that Democratic Vistas "is not in the tradition of Marxism." 37 Gold, however, treated Whitman differently. In 1934, he wrote of Whitman as part of a "native tradition of a cornfed socialism." 38 And in early June 1941, he even credited Whitman with helping prepare the way for proletarian culture and the Communist Party in America. During the Depression, "there was present a living core of Marxist thought in America," he said, "ready to shape the thought of the intellectuals" because of "the presence of a mature and firm Communist movement" which was "no Moscow plot, but the legitimate child of American parents and grandparents such as Hor[a]ce Greeley, Albert Brisbane, Eugene V. Debs, Bill Haywood, Jack London and Walt Whitman." 39 And later in the same month, hailing a translation of Whitman into Yiddish, he wrote:

Walt Whitman's democracy had its roots in the sidewalks and stretched up to the stars. It was the real thing. The old bard of America will not lag a step on the hard road that leads to world socialism. He will always be with us, for he never wrote about the people's freedom without remembering the people's bread. ${ }^{40}$

Thus, Whitman became, for Gold, a kind of pre-Communist and even a Communist saint.

During the McCarthy era, when people rushed to disaffiliate themselves from the Party, Gold remained loyal. In so doing, he was, he felt, emulating Whitman, as he indicated in "The Writer in America": "Walt might be railroaded today," for he "signed an amnesty petition for the victims of the Haymarket frameup. He felt very strongly about the case. If he felt like that about the Rosenbergs today, he would be called a 'foreign agent.' "41

Gold's political views thus clearly influenced his views of literary history. For him, the great antecedent of the twentieth-century radical writers was Whitman. And the greatness of contemporary writers in turn 
could be measured by their relation to Whitman. In 1926, for example, he praised Dos Passos's Manhattan Transfer for being "as full as a page of Walt Whitman."42 In 1930 he predicted: "There will be Negro Tolstoys, Gorkys, and Walt Whitmans."43 Again in 1930, while showing how far Thornton Wilder had strayed from what he felt to be the true path, Gold asked: "Is this the language of the intoxicated Emerson? Or the clean, rugged Thoreau, or vast Whitman?"44 And in 1941, he wrote that in Carl Sandburg's work is "some of the same note of socialism and revolt one can find in Whitman."45

Again in 1941, he said:

The Thirties compares favorably with the Civil War decade, the greatest single chapter in the history of American culture. Its importance lies in its mass character. Therefore, no single Emerson or Whitman stands out, though thousands of potential Emersons and Whitmans were formed. They are still young. ${ }^{46}$

Thus, Gold used Whitman repeatedly to demonstrate that Communism with a capital $\mathrm{C}$ was the culmination of American culture and the thing toward which American literary tradition pointed. He declared America to be "the land of Thomas Jefferson, and Walt Whitman, and the abolitionists who fought a civil war to free this land from black slavery," 47 and he saw himself as working in this same tradition when he called for a revolution to free America from wage slavery. More important for his purposes as a writer, he conceived of a revolutionary tradition in American literature leading directly to the writers affiliated with the Communist movement who were trying to start a proletarian literature. Largely ignoring Whitman's emphasis on individualism as well as the more conservative aspects of his political theorizing, Gold tried to recreate Whitman into a pre-Communist so that he could be a part - perhaps the most important part-of this tradition. For the many American creative writers and critics during the 1930s who responded to Gold's call for a proletarian literature and who linked themselves either directly or indirectly with the Communist Party, he seems to have succeeded in this recreation.

\section{East Texas State University}

\section{NOTES}

1 Michael Folsom, ed., Mike Gold: A Literary Anthology (New York: International, 1972), p. 62; Marcus Klein, Foreigners: The Making of American Literature, 1900- 1940 (Chicago: University of Chicago Press, 1981), pp. 236-237. My research on Michael Gold was supported in part by an Organized Research Grant from East Texas State University.

2 Daniel Aaron, Writers on the Left: Episodes in American Literary Communism (New York: Harcourt, Brace \& World, 1961), p. 86.

3 Klein, p. 237.

4 Michael Gold, "The Writer in America," in The Mike Gold Reader: From the Writings of Michael Gold, introd. Samuel Sillen (New York: International, 1954), pp. 182-183. 
5 Klein, p. 185.

6 Michael Gold, "Wilder: Prophet of the Genteel Christ," rev. of The Cabala, The Bridge of San Luis Rey, The Woman of Andros, The Angel that Troubled the Waters, by Thornton Wilder, New Republic, 20 October 1930, 266-267.

7 Michael Gold, "In Foggy California," New Masses, November 1928; rpt. in Folsom, p. 170.

8 Michael Gold, "Change the World!" Daily Worker, 17 October 1935, 5.

9 Michael Gold, The Hollow Men (New York: International, 1941), p. 19.

10 Michael Gold, "Out of the Fascist Unconscious," rev. of Frescoes for Mr. Rockefeller's City, by Archibald MacLeish, New Republic, 26 July 1933, 295.

11 Irwin Granich, "Towards Proletarian Art," Liberator, February 1921; rpt. in Folsom, p. 68.

12 Gay Wilson Allen, The Solitary Singer: A Critical Biography of Walt Whitman (New York: New York University Press, 1967), p. 390.

13 Michael Gold, "Go to Hell with Art Young," rev. of Art Young's Inferno, New Masses, 6 February 1934, 25-26.

14 Michael Gold, "Change the World!" Daily Worker, 17 September 1935, 5.

15 Gold, “Towards," p. 68.

16 Michael Gold, "Freemont Older," New Masses, 26 March 1935; rpt. "Freemont Older: Last of the Buffaloes," in Change the World! introd. Robert Forsythe (New York: International, 1936), p. 80.

17 Michael Gold, David Burliuk: Artist-Scholar, Father of Russian Futurism. With a Brief Sketch of Mayakovsky whom Burliuk Discovered, introd. Herman Baron (New York: A. C. A . Gallery, 1944), p. 11.

18 Folsom, p. 62.

19 Gold, "Towards," pp. 67-68.

20 Gold, “Towards," p. 68.

21 Gold, "Towards," pp. 68-69.

22 Gold, "Towards," p. 69.

23 Gold, "Towards," p. 70.

24 Walt Whitman, Leaves of Grass: The First (1855) Edition, ed. Malcolm Cowley (New York: Viking, 1959), p. 48.

25 Michael Gold, "Schools of U. S. Writing," New Masses, September 1928, 13.

26 Gold, Hollow, p. 21.

27 Gold, "Schools," 13.

28 Granville Hicks, The Great Tradition: An Interpretation of American Literature Since the Civil War (New York: Macmillan, 1933), pp. 20-21.

29 Sculley Bradley and Harold Blodgett, eds., Leaves of Grass, Comprehensive Reader's Edition (New York University Press, 1965), p. 1.

30 Michael Gold, “Change the World!” Daily Worker, 24 April 1935, 5. 
31 Melvin P. Levy, "Michael Gold," rev. of ferws Without Money, by Michael Gold, New Republic, 26 March 1930, 161.

32 Gold, "Towards," p. 68.

33 Michael Gold, “American Jungle Notes,” New Masses, December 1929, 9.

34 Michael Gold, "Notes of the Month," New Masses, September 1930, 4.

35 Michael Gold, "Why I am a Communist," New Masses, September 1932; rpt. in Folsom, p. 211.

36 Richard Chase, Walt Whitman Reconsidered (London: Golancz, 1955), pp. 154, 159.

37 Richard Chase, Walt Whitman, University of Minnesota Pamphlets on American Writers, No. 9 (Minneapolis: University of Minnesota Press, 1961), p. 38.

38 Gold, “Go," p. 25.

39 Michael Gold, “The Second American Renaissance," in Folsom, p. 249.

40 Michael Gold, "Change the World!," Daily Worker, 22 June 1941, 5.

41 Gold, "Writer," p. 183.

42 Michael Gold, “A Barbaric Poem of New York," rev. of Manhattan Transfer, by John Dos Passos, New Masses, August 1926, 25.

43 Michael Gold, "Notes of the Month," New Masses, February 1930, 3.

44 Gold, "Wilder," p. 267.

45 Gold, Hollow, p. 19.

46 Gold, "Second," p. 253.

47 Michael Gold, "A Love Note from the K.K.K." in Change the World! p. 22. 